\title{
Archiving Indigenous Knowledge on Pottery Making Among Macca Oromo: West Shoa Zone in Focus
}

\author{
Samuel Leykun \\ Assitant Professor, PhD Candidate at University of South Africa \\ Tamiru Gari \\ Lecturer, at Ambo University
}

\begin{abstract}
Indigenous knowledge is a wisdom born in the community by the community. These knowledge and wisdom play a remarkable role in socio economic development of a certain country. Pottery making is an indigenous knowledge in which made by forming a clay body into objects of a required shape and heating them to high temperatures in a kiln which removes all the water from the clay, which induces reactions that lead to permanent changes including increasing their strength and hardening and setting their shape. There may be occasions when potteries no longer have any use due to plastic and related object replacement among the many possible reasons, at least in everyday's use. This may result in the extinction (distinction) of the pottery. Furthermore some indigenous knowledge dies away with some potteries in the community. Therefore, this research will be a good beginning for the pottery making as economic empowerment among Macca Oromo, Ethiopia. The study area, west Shoa Zone; Tokkee Kuttayee, Iluu Galaan and Bakkoo Tibbee districts. For difficult to cover the whole Zone, the researchers were selected two villages from each district as study site in the region. Basically this research was created a baseline for researchers those interested on Oromo indigenous knowledge in general and Macca Oromo pottery making in particular. To mention some of the specific objectives: To revitalize the wisdom of pottery making among Macca Oromo, to indicate the role of IK for economic empowerment, and to indicate how artisan transfer their knowledge for the next generation. The major data collection instrument was questionnaire, focus group discussion, observation and interview. For such quanqualitative research, Systematic observation was assisted the researchers to master the scenario. To mention some of the findings, being asked whether they prefer pottery than modern iron products. $50(24.9 \%)$ informants strongly agree, $71(35.3 \%)$ informants responded that agree and the rest $79(39.3 \%)$ informants strongly disagree. There is statistical relationship between prefer pottery than modern iron products and use of equipments made from pottery at home (p-0.04). In addition, whether potteries are accessable from the market. Accordingly, $121(60.2 \%)$ informants are strongly agree that potteires are easily accessable from market and the rest $79(39.3 \%)$ responded strongly disagree that pottery products are not accessable from the market. As the table reveals, there is statistical relationship between accessibilities pottery and use of equipments made from pottery at home ( $\mathrm{p}-0.03$ ). The study proved that, among to Macca Oromo pottery making has three phases: Preparatory phase, Actual phase and Post phase. Pottery making is the indigenous knowledge practiced for a longer period of time among Macca Oromo.
\end{abstract}

Keywords: pottery, archive, and indigenous knowledge

DOI: $10.7176 / \mathrm{JCSD} / 52-04$

Publication date:October $31^{\text {st }} 2019$

\section{Background of the Study}

Oromoo is asserted to be the father of two tribes called Borena and Barentu, and the cradle land of these tribes is considered to be Maddawalaabu, which is found in the present Bale Zone, Ethiopia. Maddawalaabu is considered to be the nation's spiritual centre and place of pilgrimage (Mekuria, 1996; Assefa, 1993; Mohammed, 1990, as cited in Alemayehu, 2012). As the origin of the word 'Oromoo' has different suggestion, so is the term 'Oromoo language'. The phrases used for the term have been: Oromoo language, Oromiffa, or Oromic, and yet some call it Afaan Oromoo (Bender, 1976), where the latter is nowadays getting more acceptance Afaan Oromoo and Oromoo are the language and the community or society respectively. The Oromoo people are found in the North West, South East and central part of Ethiopia and consist of various groups which for centuries were exclusively made a confederation The groups in turn, were divided in to sub groups, the sub-groups into clans, and the clans into lineages. Among the major regional groups are the Borana, Guji, Arsi, Tulama, Afran Qallo, Macha, Karrayu and Wallo.

Indigenous knowledge is sometimes called traditional knowledge. To the researchers Indigenous knowledge is a wisdom born in the community by the community. These knowledge and wisdom play a remarkable role in socio economic development of a certain country. Therefore, Indigenous knowledge should documented for the next generation electronically or digitally. Mahatma Gandhi said; "you must not lose faith in humanity. Humanity is an ocean; if a few drops of the ocean are dirty, the Ocean does not become dirty." Indigenous Knowledge is unique to a particular culture and society. It is the basis for local decision-making in agriculture, health, natural 
resource management and other activities. IK is embedded in community practices, institutions, relationships and rituals. Indigenous knowledge provides the basis for problem-solving strategies for local communities, especially the poor. It represents an important component of global knowledge on development issues. IK is an underutilized resource in the development process.

According to the 1998/99 World Development Report, knowledge, not capital, is the key to sustainable social and economic development. Building on local knowledge, the basic component of any country's knowledge system, is the first step to mobilize such capital. Recent World Bank client feed-back surveys provide additional insights regarding the importance of knowledge of local institutions and practices. Indigenous knowledge is an important part of the lives of the poor. It is a integral part of the local ecosystem. IK is a key element of the "social capital" of the poor; their main asset to invest in the struggle for survival, to produce food, to provide for shelter or to achieve control of their own lives.

Pottery is made by forming a clay body into objects of a required shape and heating them to high temperatures in a kiln which removes all the water from the clay, which induces reactions that lead to permanent changes including increasing their strength and hardening and setting their shape. A clay body can be decorated before or after firing. Prior to some shaping processes, clay must be prepared. Kneading helps to ensure an even moisture content throughout the body. Air trapped within the clay body needs to be removed. This is called de-airing and can be accomplished by a machine called a vacuum pug or manually by wedging. Wedging can also help produce an even moisture content. Once a clay body has been kneaded and de-aired or wedged, it is shaped by a variety of techniques. After shaping it is dried and then fired. Pottery is the ceramic material which makes up pottery wares, of which major types include earthenware, stonewar and porcelain. The place where such wares are made is also called a pottery (plural "potteries"). Pottery also refers to the art or craft of a potter or the manufacture of pottery. Bula Sirika (2008)

There may be occasions when potteries no longer have any use due to plastic and related object replacement among the many possible reasons, at least in everyday's use. This may result in the extinction (distinction) of the pottery. Furthermore some indigenous knowledge dies away with some potteries in the community. Therefore, this research will be a good beginning for the pottery making as economic empowerment among Macca Oromo, Ethiopia. The study area, west Shoa Zone; Tokkee Kuttayee, Iluu Galaan and Bakkoo Tibbee districts. For difficult to cover the whole Zone, the researchers were selected two villages from each district as study site in the region. The study sites will select based on: the prevalence of widespread handicraft works. Now days, the "globalization" and "modernization" are affecting the indigenous knowledge of the local community in general and artisan in particular.

An archive is an accumulation of historical records or the physical place they are located. Archives contain primary source documents that have accumulated over the course of an individual or organization's lifetime, and are kept to show the function of that person or organization. Professional archivist and historians generally understand archives to be records that have been naturally and necessarily generated as a product of regular legal, commercial, administrative or social activities. They have been metaphorically defined as "the secretions of an organism" and are distinguished from documents that have been consciously written or created to communicate a particular message to posterity.

Source: https://en.wikipedia.org/wiki/Archive

\section{Conceptual Framework}

The framework revolves around four pillars:

- Disseminating information. Key actions include:

- Developing a database of IK practices, lessons learned, sources, partners, etc.

- Identifying and testing instruments for capture and dissemination of IK.

- Publishing selected cases in print and electronic format.

- Facilitating exchange of IK among developing communities. Key actions include:

- Helping build local capacity to share IK, especially among the local IK centers.

- Identifying appropriate methods of capturing, disseminating IK among communities.

- Facilitating a global network to exchange IK.

- Applying indigenous knowledge in the development process. Key actions include:

- Raising awareness of the importance of IK among development partners.

- Helping countries to prepare national policies in support of indigenous practices.

- Integrating indigenous practices in programs/projects supported by partners.

- Building partnerships. Key actions include:

- Learning from local communities and NGOs.

- Leveraging limited resources of partners to obtain greater development impact.

- Addressing the intellectual property rights issue of indigenous knowledge. Cuddan J. (1998) 


\subsection{Purpose of Archiving}

Archiving refers to recording and describing or the state of being documented. Bury (2003:46-47) gave us some common values on what would constitute a good documentary corpus;

1. Diverse- diverse in situation, in participants,

2. Large- more than ever before, the technology is therefore to be arbitrary large.

3. Ongoing- distributed and opportunistic- if continually grows,

4. Transparent- they would be properly annotated,

5. Perceivable- Ethical and portable proper Meta data information should be given about each item of data. It should be archived and handled,

6. Ethical- data ownership should be protected.

\section{Statement of the problems}

Basically this research was created a baseline for researchers those interested on Oromo indigenous knowledge in general and Macca Oromo pottery making in particular. Because pottery making touched as passing remark in different studies. Except Bula Sirika 2008 work entitle with socio-economic status of Handicraft Women among Macca Oromo of west Wallaga, Southwest Ethiopia. He stated that artisan women, who belong to social class known as ogeyyii, meaning expert, play a vital role in socio-economic life of West Wallaga. Moreover, he mentioned that women are producers of implements/utensils which the broad base of the society is putting to use in its day-to-day indoor and outdoor chores.

In the course of the study, the researchers try to answer the following research questions:

1. Why pottery making become in verge extinction?

2. How pottery making play a remarkable role in economic empowerment?

3. What are the social, cultural, psychological, and economical significance of these indigenous knowledge for a target community?

4. How can we preserve the authenticity of Indiginious knowledge of Macca Oromo in light of contemporary ethnographic contamination?

\section{Research Objectives}

\subsection{General objective of the Study}

The general objective of this is that to archive indigenous knowledge of Macca Oromo in general and pottery making in particular.

\subsection{Specific Objectives of the Study}

The specific objectives of the study are as follow:

- $\quad$ To revitalize the wisdom of pottery making among Macca Oromo.

- To indicate the role of IK for economic empowerment.

- To indicate how artisan transfer their knowledge for the next generation.

\section{Research Methods and Design}

\subsection{The Study Area}

According to the information from zone Agriculture office, West Shoa is one of the zones of the Oromia region in Ethiopia. West Shoa zone comprises about 22 districts. West Shoa zone takes its name from the kingdom or former province of Shoa. West Shoa is bordered on the south by the Southwest Shoa Zone and the Southern Nations, Nationalities and People region, on the southwest by Jimma, on the west by East Welega, on the northwest by Horo Guduru welega, on the north by the Amhara Region, on the northeast by North Shoa, and on the east by Oromia Special Zone Surrounding Finfinne. Its highest point is Mount Wanchi (3386 meters); other notable peaks include Mount Menagesha and Mount Wachacha. Towns and cities in West Shoa include Ambo, Ijaji, Bako, Gedo, Ginci, Holeta, Ejere, Guder, Sayyo, Balemi, Dire hincini and the like.

Based on the 2007 Census conducted by the Central Statistics Agency of Ethiopia (CSA), this Zone has a total population of 2,058,676, of whom 1,028,501 are men and 1,030,175 women; with an area of 14,788.78 square kilometers, West Shoa has a population density of 139.21 . While 242,352 or $6.10 \%$ are urban inhabitants, a further 53 individuals are pastoralists. A total of 428,689 households were counted in this Zone, which results in an average of 4.80 persons to a household, and 415,013 housing units. The two largest ethnic groups reported in West Shoa were the Oromo (93.82\%) and the Amhara (5.15\%); all other ethnic groups made up 1.03\% of the population. Afan Oromo was spoken as a first language by $93.99 \%$ and $5.47 \%$ spoke Amharic; the remaining $0.54 \%$ spoke all other primary languages reported. The majority of the inhabitants professed Ethiopia Orthodox Christianity, with $53.84 \%$ of the population having reported they practiced that belief, while $32.93 \%$ of the population professed Protestantism, $3.38 \%$ of the populations are followers of Muslim and $9.85 \%$ of the population said they held traditional beliefs. 


\subsection{The Study Subject}

As mentioned above the subjects of the study is West Shoa Zone Ilu Galan, Bako Tibbe and Tokke Kuttaye districs for it is difficult to cover the whole zone, the researchers were selected two villages from each districts. The study sites was selected based on: the prevalence of widespread of handicraft works in the area in which pottery makers playing vital role, the fact that currently the technologies owned by them are under great challenges that in turn are affecting artisan socio-economy and the rising need to identify the major bottlenecks hindering progress of the local technologies. The numbers of the study population is supposed to exceed a million. But the sample population is about only 30 key informants from each villages.

\subsection{Techniques of Sampling}

For this study the researchers were stick to purposive sampling technique. This technique is preferred for the researchers believe that since the subject of the research is local pottery makers. Purposive sampling will help the researchers to extract more information from local pottery makers and knowledgeable individuals purposively. In addition, random sampling is also used to extract information from the subjects.

\subsection{The Data Collection Tool}

The major data collection instrument was questionnaire, focus group discussion, observation and interview. For such qualitative research, Systematic observation was assisted the researchers to master the scenario. In addition, it helps them to know how potters make pottery, the row material used, the type of soil they used and in case if there is ingredients they add. Interview was also help the researchers the process and phases of pottery making. The researchers believed that FGD was helped to crosscheck the data and to get more information regarding their life.

\subsection{Procedures of Data Collection}

The informants were consulted about their convenient time to be interviewed and for discussion. Then the right time and place was arranged with the informant. The prepared interview questions were presented to the selected informants (potters and non-potters). The entire response of the pottery makers will record digitally by using photo camera and audio recorder while interviewing, observing and FGD.

\subsection{Metadata}

Metadata is data about data. The main purpose of metadata is to facilitate in the discovery of relevant information, more often classified as resource discovery. Metadata also help us to organize electronic resources, provide digital identification, and helps support archiving and preservation of the resource. Metadata summarizes basic information about data, which can make finding and working with particular instances of data easier. For this study the researchers were planned to use both structural metadata and descriptive metadata. Structural metadata is data about the containers of data. Descriptive metadata uses us instances of application data or the data content.

\subsection{Ethical Consideration}

In this research we were considered the ethical aspect of the project. Individuals should be treated as autonomous agents: The investigators must ensure that the subject has received a full disclosure of the nature of the study, the risks, benefits and alternatives, with an extended opportunity to ask questions. Maximize possible benefits and minimize possible harms: The investigators should give forethought to the maximization of benefits and the reduction of risk that might occur from the research. Fairness in distribution: Justice occurs when some benefit to which a person is entitled is denied without good reason or when some burden is imposed unduly, equitable selection of participants. Informed consent, Fairness in distribution, Research misconduct, Authorship and Conflicts of interest. Accordingly, our informants are not showed their interest to take their picture while dough of the clay was prepared to make pottery.

\section{FINDINGS AND ANALYSIS OF DATA 6.1 Introduction}

This part presents the analysis of responses from questionnaires. The data obtained through the questionnaires were presented in tables and their analyses were given below each table while the results of interviews were transcribed and presented thematically in the paragraphs.

\subsection{Perception of households}

This section portrays households' response to cultural, socio-economic background and usage of pottery in the study area. All the data obtained through questionnaire from the households are also presented and analysed below: 


\begin{tabular}{|c|c|c|c|c|}
\hline Variable & Category & Frequency & Percent & Chi-squere \\
\hline \multirow{4}{*}{ Income } & $0-1000$ & 50 & $24.9 \%$ & \multirow[t]{4}{*}{0.021} \\
\hline & $2001-3000$ & 71 & $35.5 \%$ & \\
\hline & $3001-4000$ & $0 \%$ & $0 \%$ & \\
\hline & Above 4001 & $79 \%$ & $39.3 \%$ & \\
\hline \multirow[t]{3}{*}{ Educational Level } & First degree & 71 & $35.3 \%$ & \multirow[t]{3}{*}{0.044} \\
\hline & Second degree & 79 & $39.3 \%$ & \\
\hline & Others & 50 & $24.9 \%$ & \\
\hline \multirow[t]{5}{*}{ Prefer pottery } & Strongly Agree & 50 & $24.9 \%$ & \multirow[t]{5}{*}{0.04} \\
\hline & Agree & 71 & 35.3 & \\
\hline & Not-decided & 0 & $0 \%$ & \\
\hline & Disagree & 0 & $0 \%$ & \\
\hline & Strongly Disagree & 79 & $39.3 \%$ & \\
\hline \multirow{5}{*}{$\begin{array}{l}\text { Accessibility in } \\
\text { Market }\end{array}$} & Strongly Agree & 121 & $60.2 \%$ & \multirow[t]{5}{*}{0.03} \\
\hline & Agree & 0 & $0 \%$ & \\
\hline & Not-decided & 0 & $0 \%$ & \\
\hline & Disagree & 0 & $0 \%$ & \\
\hline & Strongly Disagree & 79 & $39.3 \%$ & \\
\hline \multirow{5}{*}{$\begin{array}{l}\text { Durability of } \\
\text { Pottery }\end{array}$} & Strongly Agree & 71 & $35.5 \%$ & \multirow[t]{5}{*}{0.07} \\
\hline & Agree & 78 & $38.8 \%$ & \\
\hline & Not-decided & 0 & $0 \%$ & \\
\hline & Disagree & 0 & $0 \%$ & \\
\hline & Strongly Disagree & 51 & $25.4 \%$ & \\
\hline \multirow[t]{5}{*}{ Cost of pottery } & Strongly Agree & 122 & $60.7 \%$ & \multirow[t]{5}{*}{0.06} \\
\hline & Agree & 0 & $0 \%$ & \\
\hline & Not-decided & 0 & $0 \%$ & \\
\hline & Disagree & 0 & $0 \%$ & \\
\hline & Strongly Disagree & 78 & $38.8 \%$ & \\
\hline \multirow{5}{*}{$\begin{array}{l}\text { Equipment made } \\
\text { from Pottery }\end{array}$} & Strongly Agree & 0 & $0 \%$ & \multirow[t]{5}{*}{0.05} \\
\hline & Agree & 78 & $38.8 \%$ & \\
\hline & Not-decided & 2 & $1.0 \%$ & \\
\hline & Disagree & 70 & $34.8 \%$ & \\
\hline & Strongly Disagree & 50 & $24.9 \%$ & \\
\hline \multirow[t]{5}{*}{ Living Style } & Strongly Agree & 0 & $0 \%$ & \multirow[t]{5}{*}{0.041} \\
\hline & Agree & 121 & $60.2 \%$ & \\
\hline & Not-decided & 79 & $39.3 \%$ & \\
\hline & Disagree & 0 & $0 \%$ & \\
\hline & Strongly Disagree & 0 & $0 \%$ & \\
\hline \multirow{5}{*}{$\begin{array}{l}\text { Pottery as part of } \\
\text { Culture }\end{array}$} & Strongly Agree & 96 & $47.8 \%$ & \multirow[t]{5}{*}{0.054} \\
\hline & Agree & 26 & $12.9 \%$ & \\
\hline & Not-decided & 78 & $38.8 \%$ & \\
\hline & Disagree & 0 & $0 \%$ & \\
\hline & Strongly Disagree & 0 & $0 \%$ & \\
\hline
\end{tabular}

The above table reveals that the out of 200 informants the income of $50(24.9 \%)$ housholds is $0-1000 \mathrm{ETB}$. Besides 71 (35.5\%) informants resonded that their income is between 1001-2000ETB. In addition, 79 (39.3\%) informants resonded that their income is above 4001ETB monthly. As the table shows, there is statistical relationship between use of equipments made from pottery at home and their income ( $\mathrm{p}-0.021)$.

Moreover, the education level 71 (35.3\%) of informants are first degree. Further more, the education level of $79(39.3 \%)$ informants are second degree and the rest $50(24.9 \%)$ responded that other. As the table reveals, there is statistical relationship between educational background and use of equipments made from pottery at home (p0.044).

Besides, being asked whether they prefer pottery than modern iron products. 50 (24.9\%) informants strongly agree, 71(35.3\%) informants responded that agree and the rest 79 (39.3\%) informants strongly disagree. There is statistical relationship between prefer pottery than modern iron products and use of equipments made from pottery at home (p-0.04).

In addition, whether potteries are accessable from the market. Accordingly, $121(60.2 \%)$ informants are strongly agree that potteires are easily accessable from market and the rest $79(39.3 \%)$ responded strongly disagree 
that pottery products are not accessable from the market. As the table reveals, there is statistical relationship between accessibilities pottery and use of equipments made from pottery at home (p-0.03).

Further more, out of 200 informants, $71(35.5 \%)$ responded strongly agree that they use equipments made from potteries at home, $78(38.8 \%)$ responded agree, and the rest $51(25.4 \%)$ responded that strongly disagree that they doesn't use equipments made from potteries at home. As the table reveals, there is no statistical relationship between use of equipments made from pottery at home and Durability of Pottery (p-0.07).

Moreover, regarding the price of pottery $122(60.7 \%)$ informants are responded strongly agree that the cost of very chaep and the rest $70(34.8 \%)$ responded that strongly disagree that the price of pottery products are cheap. As the table shows, there is no statistical relationship between use of equipments made from pottery at home and costs of pottery (p-0.06).

Besides, being asked whether there is or there are equipments made from pottery at home. $78(38.8 \%)$ responded agree, $2(1.0 \%)$ responded not-decided, $70(34.8 \%)$ responded disagree and the rest $50(24.9 \%)$ responded that strongly disagree. As the table reveals, there is no statistical relationship between use of equipments made from pottery at home and Equipment made from Pottery (p- 0.051).

In addition, being asked whether living style can affect usage of cultural equipments like pottery at home. 121 responded that agree, the rest $79(39.3 \%)$ responded that not decided whether living style can affect usage of cultural equipments like pottery at home. As the table shows, there is statistical relationship between use of equipments made from pottery at home and living style (p- 0.041).

Finaly, being asked whether pottery is considered as a part of culture out of 200 informants 96 (47.8\%) responded that strongly disagree, $26(12.9 \%)$ responded that agree, $78(38.8 \%)$ responded that not-decided whether pottery is considered as a part of culture. As the table shows, there is no statistical relationship between use of equipments made from pottery at home and Pottery as part of Culture (p- 0.054).

\subsection{ANALYSIS OF INTERVIEWEES' RESPONSES}

The interviews conducted with potters were presented in the following sections. These potters represent only Macca Oromo particulary west shoa zone Amboo, Iluu Galaan, and Bakkoo Tibbee districts in the Oromia Regional State. Their responses to the interviews were transcribed and presented below.

\subsubsection{INTERVIEWEE PM1}

Interviewee PM1 was a pottery maker and she make pottery to support her life. She acqiured this indigenous knowledge from her mother. She has been ingaged in pottery making fro the last 30 years.

1. According to the interviewee, the type soil used to make pottery is unique. Its name is not soil, just clay soil. We pay 100 birr annualy to collect the clay soil. The soil which used to make pottery is not collected from anywhere. Like I said the honor of he land collect 100 birr from every one us.

2. Moreover, usually I prefered to dug the soil before the sun went down or early in the morning. Because, this time is good for digging. After I dug the soil from digging area, I took home keep for two days in air and spread out in sun.

3. Besides, after spread in sun we grind or make powder using stron stick.

4. In addition, the reason for spread out in sun is that easly kneaded. The dough of such soil which spread out in sun is unique and easly became fertmented within a short period of time. Then mixed togather the clay soil with water.

5. On the other hand, the clay soil is easily quarrelling with water. Most of the time women kneaded. However, it is by far better if men kneaded. Because, it can used to keep the strenght of the pottery. After that I make griddle or disc of clay in which bread or buddeena is made.

6. Besides, before a long period of time small griddle which help to roast coffee is made of clay soil. However, now a day disc of iron on which coffee is roasted or any snack taken while drinking coffee is replaced the traditional one. There is slit difference between the soil which used to make small pot and griddle. The clay soil which used to make small pot, jar, and pot is grey one. Whereas, the clay soil which used to make griddle is the slitely black one. Their difference is in color. Clay the essential ingredient for pottery and ceramics. Taken from the earth, processed and refined it becomes, in the artist s' hands, capable of producing objects of extreme beauty. Edgar E. (2013).

\subsubsection{INTERVIEWEE PM2}

Interviewee PM1 was a pottery maker and she make pottery to support her life. Her husband died 8 years back. She has 6 children. She acqiured this indigenous knowledge from her family. She was ingaged in pottery making for the last 27 years.

1. According to the interviewee pottery making process ought to be contains the following stepts: The process of pottery making is start from dug the clay soil to present the product for market. Before present to the market pottery making gone through different steps.

2. Furthermore, from clay soil different home equipments are made small pot, griddle, pot, jar, gallon, and so forth. Potters support their life by selling this this equipments. The cost of these equipments are very 
low. Some time no one is buy this product because of the materials replaced by iron product.

3. In addition, sooner after a pottery is made, it is impossible to set into motion because, it maght be broken easily. To strenghen the pottery usualy potters used a wood that can easily be transformed into charcoal. Such wood help to increase the strenght of the materials made from clay soil.

4. Besides, they used peices of broken glass or glaze as sand-paper to make it beautify or attractive. The color of srong pottery is brown. The one who purchease is also check before buying the materials by nocking. It is believed that srong pottery produces a metal sound when someone nocked or tapped for the body of it.

\subsubsection{INTERVIEWEE PM3}

Interviewee PM1 was a pottery maker and she make pottery to support her life. She is know in the village as hadha suphee [hada sup'e:] means mother of pottery. She has 11 children. Her husband is farmer. She acqiured this indigenous knowledge from her mother. She was ingaged in pottery making for the last 32 years.

1. According to the interviewee the type of soil which used to make pottery ought to be biyyee suphee [bij:e: sup'e:] means clay soil. In pottery making the type of soil used play its role. Any type of soil can't be used to make pottery. Clay is one of the most satisfying materials to work with. It consists of millions of tiny plate-shaped particles. Water enables these particles to slide over each other without breaking. When a clay body is about $20 \%$ water it is easily moulded. Man has used clay throughout the centuries to produce both functional and decorative wares Edgar E. (2013).

2. In addition, the type of soil used is uneque and its name is biyyee suphee [bij:e: sup'e] means clay soil. This soil is not found any where. The topography can play its role in the location of soil used for clay. Such type of soil usualy found around the cave.

3. Moreover, the color of this soil is special when compare with other type of soil found around. For instance, in the study areas the color of the soil is biyyee kootichaa [bij:e: kotiča:] which means black soil. Whereas, the color of the soil which used to make pottery is biyyee diimaa [bij:e: di:ma:] means red soil.

4. Besides, in the same topography the color of clay soil is unique and special by its nature. This type of soil is not used for farming. By its nature this soil contains clay sand and pieces of stone in it. According to the informans such type of land with clay soil is not easily plough. Therefore, no one is going to use this type soils except the potters. More explicitly, even potters themselves are not use this soil frequently. Pottery making is seasonal in the study area.

\subsection{Phases of Pottery Making among Macca Oromo}

Based on the results of the study, among to Macca Oromo pottery making has three phases. These phases are presented as follows:

1. Preparatory phase,

2. Actual phase and

3. Post phase.

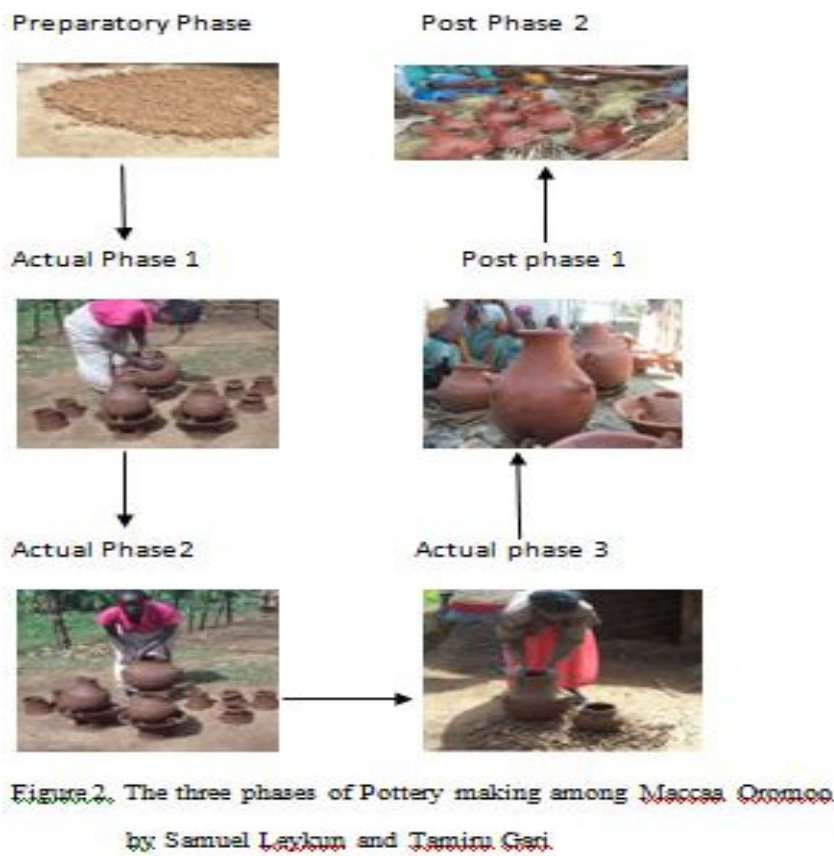

Different activities are expected from each phases. The preparatory phase contains from preparation area for pottery making to digging the soil which used for pottery making. In this phase a potters ought to collect all 
neccessary equipment and row materials used to make pottery.

More explicitly, potters start their work by preparing open and free area to perform wisdom in their village. Then, they go for digging clay soil. The availability of clay soil is different from palce to place. For instance, around shoboka 1 / oboka/ clay soil is easily accessable without any payment. A palce where clay soil dug is known as lafa borki /läfä bok'i/ literaly mean a land which is not used for plaughing. Whereas, around $\mathrm{kibaa}^{2} / \mathrm{k}$ 'iba:/ accessable but it is expected from potters to pay limmited amount of money annualy. After that they dug for the clay soil, potters usually take home, spread out in sun and make ready for knead. Potters spread out the clay soil in sun for at least for three days. This has the following advantages: To increase the strenth of the pottery,

To mixed togather the clay soil with water and To knead easily.

The next phase is a phase when the main activities of a pottery making is performed. This phase contains from knead the clay soil to beautify and make ready for the market. In this phase potters mixed togather the clay soil with water and knead. According to the informants, it is recommended if men knead for the clay soil. This has multiple advantage. In the first glance the clay soil easily mixed up with the water. This has its own advantage in the strengthning the final product of the pottery. Before embark to knead potters add small amount of yeast to clay soil and water. Yeast in this case is a leaven dough from the last dough mixture. After that potters start to mixed with water and kneaded the clay soil. Usually potters kept the kneaded clay siol for two consiquative days. Then potters mix the dough of with water for the last time and start making any king of clay product from the prepared clay dough.

The last phase is post pottery making phase. This phase contains from beautify to present the final product for market. In this phase potters stiffened to strengthen the pottery. It is fired at low temperatures so that the next generation will able to use their cultural equipments and to produce very functional and durable pottery. In addition, they scrach to beautify the final product using pieces of broken glasses. At this stage pottery product is ready for celling. Finally, the final product of pottery will present for market.

Pottery making is not overnightwork. As stated above based on the finding of this study, three major phases are identified. Under this phases there are major activities to be done by potters. The following figure manifest that the major activities done by potters to make pottery.

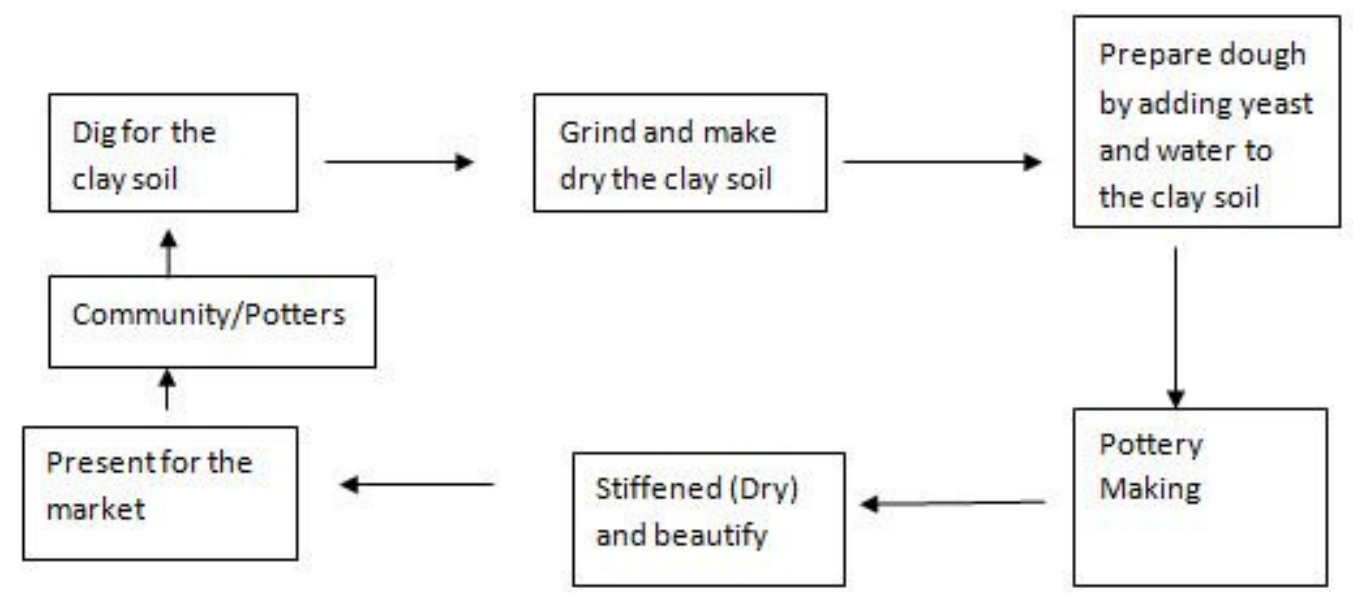

Figure 1 Process of pottery making among Macca Oromoo.

The above figure reveals the process in which pottery is produced. The above figure, shows community or potters are initial step for pottery making. In the process of pottery making, potters ought to dig for the clay soil first, grind and make dry the clay soil and prepared dough by adding yeast and water to the clay soil are categorized under the preparatory phase. In addition, make pottery is categorized under the actual phase of pottery preparation. Besides, stiffened or dry and beautify the pottery product, and present for the market are categorized under post pottery making phase.

\subsection{Conclusion}

Pottery making is the indigenous knowledge practiced for a longer period of time among Macca Oromo. Currently, in the study area pottery making become in verge of extniction. In addition, according to the informants the name

\footnotetext{
${ }^{1}$ Bakkoo Tibbee district.

${ }^{2}$ Ambo district.
} 
given to potters are suphee dhooftuu [sup'e doftu:].

The main participant of this indigenous knowledge is women. According to the informants, women are the main actors of pottery making among Maccaa Oromo. For women, pottery making considered as a means to increase their income. In addition, women used pottery making to support their family.

According to the informants earthenware is used by the Macca Oromo when they cook. Potters, who are predominantly women, make cooking vessels using locally available clay and then distribute the completed products throughout the area.

The raw clay arrives from the quarry and crushed manually, the crushed clay is then deposit into a blunger where yeast and water are added, then the clay slurry is ready, and finally potters start making pottery.

\section{Bibliography}

Asaffa Jalata (1998). The culture roots of Oromo. The red sea press. Eritrea: Asmara 337pg

Asmarom Leggese (1973). Gada: Three approaches to the study of African society. The free press. New York $412 \mathrm{pg}$

Assimeng, M. (1989). Religion and social change in west Africa. Ghana university press. Ghana: Accra 318pg Peter A. (2010) Language Documentation and Description. Hanz rouse publisher. London 413pg.

Bartels L. (1983). Oromo religion; myths and rites of the western Oromo of Ethiopia an attempt to understand. reomer verlay press. Berlin 487pg

Baye Yimam (1986). The Phrase Structure of Ethiopian Oromo group. Unpublished M.A. Thesis defended at AAU.

Beletech. D. (2003). Oromtitti; the Forgotten Women in Ethiopia History. lvy house publisher USA 265pg.

Bula Sirika (2008). Socio-economic Status of Handicraft Women Among Macca Oromo of West Wallaga, Southwest Ethiopia Ethiop. J. Educ. \& Sc. vol. 4 No. 1

Cluode S. (1995). Proverbs, songs, folktales: An anthology of Oromo literature. Central printing press. Ethiopia: Addis Ababa 295pg

Cotter G. (1992) proverbs and sayings of Oromo people of Ethiopia and kenya with English translation. The Edwin Mallon press. .New York 332pg.

Cuddan J. (1998). The penguin dictionary of literary terms and literary theory. Itd.ivas plc. England 642pg

De salviac M. (1901) An ancient people, Great African of nation: the Oromo. Sage Publisher. France: Paris 212pg.

Dirribi damuse (2009) Ilaalcha Oromo. D.G printing and publishing enterprise. Ethiopia: Finfinne 596pg

Dorson R. (1972). Folklore and folklife: An introduction. The University of Chicago press. Chicago 318pg

Durkheim E. (1965). The elementary form of religious life. Free press. New York 384pg

Durkheim E. (1963). Primitive classifications. The University of Chicago press. Chicago 401pg.

Evens-Pritchard (1969). Nuer religion. at the Clarendon press. Oxford. 345pg.

Finnegan R. (1970). Oral literature in Africa. oxford university press. Kenya: Nairobi $213 p g$.

Frazer, J.R (1890). The golden bough. Macmillan press UK: London 432pg.

Gada, Melba. (1988) Oromia: an introduction. Khartoum University press. Sudan: Khartoum 272pg.

Gadaa Melba (1999). Oromia: an introduction to the history of the Oromo people. Kirl house publisher. US: Mennisota. 412pg.

Gammachu Magarsa (1998). The Oromo world view. In international sciplinary seminar of the institute of Ethiopian studies, vol 1 no 4 pp 41-54 Nazreth.

George L. and mark T. (1980). More than cool reason: a field guide to poetic Metaphor. The University of Chicago press. Chicago 375pg.

GuestG, Mack, N, McQueen M, Namey E and Woodsong C (2005) qualitative research methods: a data collectors field guid. family health international publisher. USA $411 \mathrm{pg}$.

Kallacha Oromia Chanalew Ginbar "Adaa"(4 October 2010) news paper.

Knutson K.E. (1967). Authority and change. A study of the Qalluu institution among the macha Oromo of Ethiopia. Ethnologiskia studier 29. Gothenburg.

Levy, B.L (1928). The soul of primitive. Allen and unwin publisher UK: London 342pg.

Lofland, J (1972) Analyzing social setting. Wadsworth publisher. Belmant $351 \mathrm{pg}$.

Mohammed, Hasen. (1994). The Oromo of Ethiopia; a history 1570-1860. The red sea press. UK 468pg.

Morie Kaneko (2009) Variations in Pottery Making in Southwestern Ethiopia. Proceedings of the 16th International Conference of Ethiopian Studise, ed. by Svein Ege, Harald Aspen, Birhanu Teferra and Shiferaw Bekele, Trondheim 2009

Okpewho, I. (1992). African literature; background character and continuity. Indiana university prees. Bloomington and Indiana polis 619pg.

Parrinder G. (1969). Religion in Africa. The pall mall press. Great Britain 463pg.

Samuel Leykun and Welde Eshetu (2012). Documentation of Moribund Oromo Lexicon: Bale Oromo in Focus. Saabruchen: LAMBERT Acadamic Publisher.

Sumner C. (1995). Oromo wisdom literature. Proverbs collection and analysis. guddina tumsa foundation 
publisher Ethiopia: Addis Ababa 218pg.

Tilahun Gamta (1993). The journal of Oromo studies. Qubee Afaan Oromo: reasons for Choosing the Latin script for development an Oromo alphabet.Vol 1 (1) Pp 36-40.

Tylor E.B (1865). Research in to the early history of mankind and the development of civilization. Harvard university press. London $318 \mathrm{pg}$.

World Bank (1998). Indigenous Knowledge For Development A Framework For Action.

Yeshambel Mulat (2013). Indigenous Knowledge Practices in Soil Conservation at Konso People, South westernEthiopia. http://jaesnet.com/journals/jaes/Vol_2_No_2_December_201 3/1.pdf

Zelalem Terefa (2002). Continuity and Change in Oromo Administrative Practices $\left(16^{\text {th }}-19^{\text {th }}\right.$ century. Unpublished compiled material.

\section{Websites}

https://en.wikipedia.org/wiki/Archive

http://whatis.techtarget.com/definition/metadata 